\title{
Utterance-Level Word Class Characteristics in Normal Elderly Women
}

\author{
Jiyoung Kim ${ }^{\mathrm{a}}$, Sangkyu Seo ${ }^{\mathrm{b}}$, Sung-Rae Cho ${ }^{\mathrm{c}}$, HyangHee Kim ${ }^{\mathrm{a}, \mathrm{c}}$ \\ ${ }^{a}$ Graduate Program in Speech-Language Pathology, Yonsei University, Seoul, Korea \\ ${ }^{b}$ Department of Korean Language and Literature, Yonsei University, Seoul, Korea \\ 'Department of Rehabilitation Medicine, Research Institute of Rehabilitation Medicine, Yonsei University College of Medicine, Seoul, Korea
}

\author{
Correspondence: HyangHee Kim, $\mathrm{PhD}$ \\ Graduate Program in Speech-Language Pathology, \\ Yonsei University, 50 Yonsei-ro, Seodaemun-gu, \\ Seoul 120-749, Korea \\ Tel: +82-2-2228-3900 \\ Fax: +82-2-2227-7984 \\ E-mail: h.kim@yonsei.ac.kr
}

Received: June 27, 2014

Revised: July 22, 2014

Accepted: September 10, 2014

This paper was summarized from the master's thesis of the first author (2014).

\begin{abstract}
Objectives: Expressive language ability can be analyzed grammatically by examining the production of word classes. This study aims to analyze the characteristics of elderly people's utterances by looking at word classes in spontaneous speech. Methods: Spontaneous speech from 35 young females and 35 elderly females was collected. Word classes were divided by three criteria (form, function, and meaning). The real usage frequency of each instance of a word class (token) and the frequency of occurrence of each word class (type), type-token ratio (TTR), were calculated. Results: For the form category, in both type and token count, the use of inflected words was lower among elderly people, while the use of uninflected words was higher. TTR of inflected words was lower in elderly people. For the functional category, the tokens for substantives were higher among elderly people, while both the types and tokens of inflectional words were lower. For the semantic category, the tokens for verbs were higher but TTR of verbs was lower. The tokens and types for adjectives were both lower among elderly people. Additional experiments showed that the predicative use of inflectional words is more frequent than the attributive use among the elderly. Conclusion: This analysis was conducted with three word class criteria to find various speech characteristics. Further study on word class in language production needs to be conducted while considering factors, such as education and gender.
\end{abstract}

Keywords: Elderly, Word class, Token, Type, Type-token ratio (TTR)
노년기에는 신체적인 기능이나 건강이 약화되고, 이러한 변화로 인해 이전에 가능했던 활동들이 어려워질 수 있는데, 이러한 변화 중 하나가 바로 의사소통능력이다(Kim \& Kim, 2009). 우리나라 노 년층이 겪는 일상생활에서의 곤란함 중 의사소통의 어려움은 가 장 높은 비율을 차지한다(Kim \& Choi, 2012). 특히 인지-화용언어 능력은 연령이 증가함에 따라 점차 저하되는 양상을 보이는데, 노 년기에 나타나는 인지-화용언어상의 문제는 일상생활, 사회 및 직 업생활에서 의사를 표현하는 데에 어려움을 초래한다(Park, 2013). 다양한 상황에서 노년층의 언어표현 능력을 살펴보기 위해 대화, 그림 설명, 이야기 말하기 과제에서 발화를 분석한 연구(Cheon, 2011)와 대화와 그림 설명 과제에서 발화 특성을 비교한 연구(Lee $\& \mathrm{Kim}, 2001)$ 에서는 정상 노화 과정에 나타나는 담화 특성인 정보 전달력 및 담화의 양적 감소를 공통적으로 보여주었다. 이러한 특
징을 구체적으로 살펴보면, 노년기에 접어들수록 사용하는 문장의 복잡성이 단순해지고 문장의 길이가 짧아지며 뿐만 아니라 서술어 의 사용이 적어진다(Kang, 2008). 뿐만 아니라 서술어의 사용이 적 고, 구어수행과제에서 다른 연령층에 비해 오류율이 높아진다. 이 렇게 의사소통에서 큰 어려움을 가지는 노인들의 언어능력 증진을 위해서는 체계적이고 분석적인 접근을 시도하여야 하며, 효과적인 의사소통을 이끌어 낼 수 있도록 다양한 전략을 사용할 필요가 있 다(Park \& Kim, 2013).

일반 노년층의 의사소통 능력 중 가장 활발히 연구되는 영역은 언어표현 능력과 관련된 분야로서 그 중 단어 정의하기, 품사, 이름 대기와 같은 의미론적 측면의 연구가 가장 높은 비중을 차지한다 (Kim \& Choi, 2012). 단어 정의하기 능력이나 발화 시 사용하는 단 어의 품사를 분석한 연구는 정상 노년층은 단어 정의하기 능력이 
감퇴되고(Kim \& Kim, 2009), 명사에 비해 동사나 대명사의 사용 이 늘어난다(Critchley, 1984)고 하였다. 이처럼 노년층의 언어를 분 석적으로 접근하기 위한 방법으로 품사 분류 분석을 시도할 수 있 는데, 품사를 연구하는 이유로는 첫째, 문법적인 측면에서 표현 양 상을 살펴보기 위함이고(Park \& Kim, 2013), 둘째, 품사로부터 대 화의 내용이나 위치를 확인하여 문법적 행위를 파악할 수 있기 때 문이며(Park \& Kim, 2013), 셋째, 품사 연구를 통해 단어 파생과 합 성 등 단어에 나타난 화자들의 언어능력을 도출해 낼 수도 있다. 이 러한 발화의 문법적 분석이 필요한 이유는 국어 문법이 구어 산출 에 미치는 영향 때문이다. 국어 문법은 자기 생각을 선명하고 명석 하게 표현할 수 있는 능력을 가지게 한다(Nam \& Koh, 2011). 문법 은 남의 생각이나 자기 생각을 정확하게 수용 또는 표현할 수 있게 하는 능력을 기르는 데 핵심적인 구실을 한다. 그러므로 문법적 분 석에서 주요한 요소인 품사가 언어표현 능력을 나타내는 변별력 있 는 요인으로 작용할 수 있도록 유의미한 결과를 이끌어 낼 수 있는 분석이 필요하다.

품사 분석에 관한 앞선 선행연구들의 특징은 첫째, 동일 연령대 집단의 품사산출 양상을 비교하였다. 둘째, 집단 간에 차이를 보이 는 품사에 대해 초점을 맞추지 않고, 집단 내에서 고빈도로 나타난 품사 즉 명사, 동사, 조사에만 초점을 맞추어 분석하였다. 셋째, 산 출한 품사의 빈도수(token)만을 측정하였고, 유형수(type)와 어휘 다양도(TTR)를 측정하지 않았다. 이러한 선행 연구들의 결과를 살 펴보면, 동일 연령대 집단 간의 품사산출 양상을 비교한 연구에서 집단 간에 전반적으로 유의미한 차이가 나타나지 않았다. 또한 정 상군과 장애군 모두 명사, 동사, 조사의 비율이 가장 높은 것으로 나타났다. 고빈도 품사인 명사, 동사, 조사는 많은 선행연구에서 언 급되고 있으며, 특히 동사와 명사의 수행력을 비교한 연구들이 많 다. 하지만 집단 내 고빈도 품사에만 초점을 두는 것이 아니라 집단 간 차이를 보이는 품사에 대한 분석에 초점을 맞출 필요가 있다. 또 한 각 품사를 얼마나산출했는가를 보기 위한 품사별 빈도수를 측 정하여 양적인 특성을 비교할 뿐 아니라 각 품사별로 얼마나 다양 한 낱말을 산출하였는가를 보기 위한 유형수와, 어휘다양도를 구 하여 발화의 질적인 특성을 알아보고자 한다. 품사의 빈도수와 유 형수 두 가지 측면에서 살펴봄으로써 특정 품사가 사용 빈도는 높 지만 종류가 적다든지, 빈도는 낮지만 종류가 많다든지 등의 더욱 구체적인 사용 양상을 알 수 있다(Lee, 2010). 빈도수는 학습자가 얼마나 많은 수의 어휘를 사용하느냐를 알 수 있는 수치이며 유창 성과 관련이 있다. 유형수는 학습자가 적절한 곳에 적절한 단어를 사용할 수 있는가와 관련되기 때문에 언어사용에서 의미적인 다양 성과 관련이 있다(Lee, Park, Park, \& Kim, 2003). 또한 빈도수로 유
형수를 나눈 값인 어휘다양도를 구할 수 있다.

한 가지 분류 방법만으로 품사로부터 발화 특성을 분석해내는 것이 적합하지 않다고 본다. 따라서 품사 분석 시에 품사의 분류기 준인 형식, 기능, 의미에 따라 분류하여 각각의 양상을 다각적으로 비교하고자 한다. 품사 분류 시 가장 먼저 고려되어야할 기준은 '형 식'으로 단어의 형태가 변하는가, 변하지 않는가의 여부를 보며, 불 변어는 그 형태가 변하지 않는 단어이고 가변어는 그 형태가 변하 는 단어이다(Nam \& Koh, 2011). 다음 기준은 '기능'인데, 단어와 단어의 관계와 문장을 만드는 작용의 관계를 뜻하며 체언, 용언, 수 식언, 독립언, 관계언으로 나눈다. 마지막 기준으로 ‘의미'는 단어가 가지고 있는 각각의 사전적 의미가 아니라 품사 분류에 필요한 것 은 형식적인 의미로서 명사, 수사, 대명사, 형용사, 동사, 지정사, 부 사, 관형사, 감탄사, 조사로 나눈다(Choi, 1991).

본 연구에서는 일반 노년층과 청년층이 자발화에서 분류방법(형 식, 기능, 의미)에 따라 산출된 품사의 빈도수의 비율과 유형수의 비율, 어휘다양도를 구하여 집단 간 차이를 비교하였고, 이에 따른 노년층의 발화특성을 도출하였다.

\section{연구 방법}

\section{연구 대상}

본 연구의 대상자는 서울지역에 거주하는 일반 성인 여성으로, 노년층은 만 70 세 이상 89 세 이하, 청년층은 만 20세 이상 39세 이 하로 선정하였다. 피험자 수는 노년층 35 명, 청년층 35 명으로, 총 70 명이었다(Table 1).

여기서 일반 성인이란, (1) Korean-Mini Mental State Examination (K-MMSE)검사를 실시하여, 연령 및 교육 수준을 고려하여 기준점수의 -1 SD 이상에 속하며(Kang, 2006), (2) 시력 및 청력에 이상이 없으며, (3) 뇌손상으로 인한 신경학적 손상을 받은 과거력 이 없고, (4) 말언어장애나 인지장애로 진단받은 과거력이 없는 사 람을 지칭한다. 이때, 교육년수에 따라 품사산출에 통계적으로 유 의한 차이를 보여 집단 간에 교육년수에 의한 영향력이 유의한 것 으로 보였다.

Table 1. Characteristics of participants

\begin{tabular}{lccrr}
\hline Group & Age (yr) & Gender & \multicolumn{1}{c}{$\begin{array}{c}\text { Education } \\
\text { level }(\mathrm{yr})\end{array}$} & K-MMSE \\
\hline Elderly $(\mathrm{N}=35)$ & $75.8 \pm 4.6$ & Female & $9.23 \pm 3.1$ & $27.0 \pm 1.7$ \\
Young $(\mathrm{N}=35)$ & $29.3 \pm 3.7$ & Female & $16.34 \pm 0.9$ & $30.0 \pm 0.0$ \\
\hline
\end{tabular}

K-MMSE $=$ Korean-Mini Mental State Examination. 


\section{연구 도구}

본 연구에서는 개방질문형 자발화 과제를 사용하였다. 과제의 주제는 첫째, 건강관리, 둘째, 여행 경험에 대하여 발화를 유도하여 실시하였다. 먼저, 피험자에게 최대한 편안하고 자연스러운 발화를 산출하도록 지시하였다. 지시사항은 "자연스러운 대화에서의 말 의 특징을 연구하기 위해 본 인터뷰를 합니다. 두 가지 질문을 드릴 것인데, 평소 말하듯이 편안하게 말씀해주세요.”였다. 그 다음, 각 집단에 동일한 두 가지 질문을 실시하였다. 첫 번째 질문은 “요즘 건강관리는 어떻게 하시나요?”였으며, 두 번째 질문은 “기억에 남 는 여행지에 대해서 말씀해주세요.”였다. 두 질문에 대한 총 발화시 간은 최소 2 분 이상 지속하도록 하였다.

이때, 질문에 단답형으로 답하거나, 발화를 충분히 산출하지 않 을 경우, 추가 질문을 하였다. 첫 번째 질문의 추가질문은 "평소에 하는 운동이나, 식사 시에 신경 쓰는 것이 더 있나요?" 또는 "건강 에 대해서 하고 싶은 말씀이 더 있나요?”였다. 두 번째 질문의 추가 질문은 “그 여행지에서 특히 기억에 남았던 일이 있나요?” 또는 “여 행에 대해서 더 하고 싶은 말씀이 있나요?"였다.

\section{연구 절차}

녹음된 대상자의 발화는 첫 시작부터 끝까지 전사하되, 발화를 약 2 분 30 초 이상 지속한 경우, 약 2 분 30 초까지의 발화만 전사하고 이후의 발화내용은 삭제하였다. 품사 분류(Table 2)시에 기준에 맞

Table 2. Categorization of word class

\begin{tabular}{|c|c|c|c|c|}
\hline \multicolumn{3}{|c|}{ Categorization (Choi, 1991) } & \multirow{2}{*}{$\begin{array}{l}\text { Analysis } \\
\text { tag }\end{array}$} & \multirow{2}{*}{ Note } \\
\hline Form & Function & Meaning & & \\
\hline \multirow{7}{*}{$\begin{array}{l}\text { Uninflected } \\
\text { words }\end{array}$} & \multirow[t]{3}{*}{ Substantive } & Noun & NN & \multirow[t]{6}{*}{ All kinds of nouns } \\
\hline & & Pronoun & NP & \\
\hline & & Numeral & NR & \\
\hline & \multirow[t]{2}{*}{ Modifier } & Determiner & MM & \\
\hline & & Adverb & $\mathrm{MA}$ & \\
\hline & \multirow{2}{*}{$\begin{array}{l}\text { Independent word } \\
\text { Relative word }\end{array}$} & Exclamation & IC & \\
\hline & & Particle & JK & All kinds of particle \\
\hline \multirow{4}{*}{$\begin{array}{l}\text { Inflected } \\
\text { words }\end{array}$} & \multirow[t]{4}{*}{ Inflectional word } & Verb & W & \multirow{4}{*}{$\begin{array}{l}\text { Auxiliary verb: WX } \\
\text { Auxiliary adjective: VAX } \\
\text { All kinds of nouns }\end{array}$} \\
\hline & & Adjective & VA & \\
\hline & & Copula & VC & \\
\hline & & Exclamation & NN & \\
\hline
\end{tabular}

추기 애매하거나, 둘 이상의 문법적 성질을 가지고 있을 경우, 국립 국어원의 표준국어대사전의 품사 정의와 '품사 분류 기본 기준 (Appendix 1)'에 따랐다.

각 대상자의 발화에서 품사의 사용 '비율(rate)'과 '개수(frequency)'를 빈도수(token)와 유형수(type)로 나타내었다. 이때 '비율(rate)' 은 각 품사별로 산출한 횟수를 전체 산출한 품사로 나누어 100 을 곱하여 나타낸 백분율을 뜻한다. 이를 통해 발화량에 상관없이 발 화내의 품사의 사용 비율을 측정하고자 하였다. 빈도수(token)는 각 품사가 실제로 사용된 총 횟수이고, 유형수(type)는 개별 품사 유형의 출현 횟수를 말한다. 이에 따라 자발화에서 도출한 항목은 빈도수 개수(frequency of token), 유형수 개수(frequency of type), 빈도수 비율(rate of token), 유형수 비율(rate of type), 어휘다양도 (TTR)이다. 어휘다양도는 품사의 유형수 개수(frequency of type) 를 빈도수 개수(frequency of token)로 나누어 계산하였다. 본 연구 에서는 품사의 빈도수 비율(rate of token), 유형수 비율(rate of type), 어휘다양도(TTR)를 집단 간 비교하여 통계적 분석을 하였다.

\section{자료 및 통계분석}

PASW 18.0을 이용하여 통계적 검증을 하였다. 노년층과 청년층 간에 형식·기능·의미적 분류에 따른 품사 사용 비율의 차이를 살 펴보기 위하여, 각 품사의 '빈도수 비율, '유형수 비율, '어휘다양도' 를 비교하였다. 이때 집단 간에 교육년수에 의한 영향이 있었으므 로, 교육년수를 공변량으로 한 공분산분석을 실시하였으며 유의 수준은.05로 하였다.

\section{연구 결과}

\section{형식적 분류에 따른 품사}

Table 3에서 살펴보면, 가변어의 경우 노년층은 청년층보다 유의 하게 더 적은 빈도수 $(F=8.885, p=.004)$ 를, 그리고 더 적은 유형수 $(F=35.262, p<.001)$ 를 사용하였다. 이때 가변어의 어휘다양도는 노년층이 유의하게 더 낮았다 $(F=6.541, p=.013)$. 불변어의 경우 노 년층은 유의하게 더 많은 빈도수 $(F=8.885, p=.004)$ 를, 그리고 더

Table 3. Descriptive statistics for rate, TTR of word class by form category

\begin{tabular}{|c|c|c|c|c|c|c|}
\hline \multirow{2}{*}{ Word class } & \multicolumn{3}{|c|}{ Elderly (N=35) } & \multicolumn{3}{|c|}{ Young ( $\mathrm{N}=35$ ) } \\
\hline & Token & Type & TRR & Token & Type & TTR \\
\hline Inflected word (\%) & $26.9 \pm 3.3$ & $23.6 \pm 3.0$ & $.49 \pm .08$ & $32.3 \pm 3.4$ & $31.7 \pm 3.2$ & $.53 \pm .06$ \\
\hline Uninflected word (\%) & $73.1 \pm 3.3$ & $76.4 \pm 3.0$ & $.58 \pm .06$ & $67.7 \pm 3.4$ & $68.3 \pm 3.2$ & $.54 \pm .05$ \\
\hline
\end{tabular}

Values are presented as mean \pm SD.

TTR=type-token ratio. 
많은 유형수 $(F=35.260, p<.001)$ 를 사용하였다.

\section{기능적 분류에 따른 품사}

Table 4에서 살펴보면, 첫째, 체언의 경우 노년층은 청년층보다 유의하게 더 많은 빈도수 $(F=10.204, p=.002)$ 를 사용하였다. 둘째, 용언의 경우 노년층은 유의하게 더 적은 빈도수 $(F=8.885, p=.004)$ 를, 그리고 더 적은 유형수 $(F=35.262, p<.001)$ 를 사용하였다. 이때 용언의 어휘다양도는 노년층이 유의하게 낮았다 $(F=6.541, p=.013)$. 셋째, 수식언의 경우 노년층은 유의하게 더 적은 빈도수 $(F=8.984$, $p=.004)$ 를 사용하였다. 넷째, 독립언의 경우 노년층은 유의하게 더 많은 유형수 $(F=7.934, p=.006)$ 를 사용하였다.

\section{의미적 분류에 따른 품사}

Table 5 를 살펴보면, 첫째, 대명사의 경우 노년층은 청년층보다 유의하게 더 많은 빈도수 $(F=10.597, p=.002)$ 를, 더 많은 유형수 $(F=10.728, p=.002)$ 를 사용하였다. 둘째, 동사의 경우 노년층은 유 의하게 더 많은 빈도수 $(F=4.541, p=.037)$ 를 사용하였다. 이때 동
사의 어휘다양도는 노년층이 유의하게 더 낮았다 $(F=5.959, p=.017)$. 셋째, 형용사의 경우 노년층은 유의하게 더 적은 빈도수 $(F=81.410$, $p<.001)$ 를, 더 적은 유형수 $(F=104.452, p<.001)$ 를 사용하였다. 넷 째, 부사의 경우 노년층은 유의하게 더 적은 빈도수 $(F=10.072, p=$ $.002)$ 를, 더 적은 유형수 $(F=4.354, p=.041)$ 를 사용하였다. 다섯째, 감탄사의 경우 노년층은 유의하게 더 많은 유형수 $(F=7.934, p=.006)$ 를 사용하였다.

\section{추가 분석}

\section{용언(동사, 형용사, 지정사)의 관형적 용법과 서술적 용법}

두 집단 간 산출 양상에 두드러진 차이를 보였던 품사는 동사와 형용사를 포함한 용언이었다. 노년층이 청년층에 비해 용언의 사용 이 유의하게 줄어든 것이다. 이러한 결과의 구체적인 사용 양상을 분석하기 위해, 산출한 용언을 관형적 용법(attributive use)과 서술 적 용법(predicative use)으로 나누어 살펴보았다. 여기서 관형적 용 법은 한정적 용법(modifying use)이라고도 하며, 체언 앞에서 위치 하여 해당 체언의 의미를 한정하는 쓰임을 말한다. 서술적 용법은

Table 4. Descriptive statistics for rate, TTR of word classes by functional category

\begin{tabular}{|c|c|c|c|c|c|c|}
\hline \multirow{2}{*}{ Word class } & \multicolumn{3}{|c|}{ Elderly $(\mathrm{N}=35)$} & \multicolumn{3}{|c|}{ Young (N=35) } \\
\hline & Token & Type & TR & Token & Type & TTR \\
\hline Substantive (\%) & $35.1 \pm 4.6$ & $44.1 \pm 5.2$ & $.69 \pm .08$ & $31.2 \pm 2.3$ & $38.6 \pm 3.5$ & $.66 \pm .07$ \\
\hline Inflectional words (\%) & $26.9 \pm 3.3$ & $23.6 \pm 3.0$ & $.48 \pm .08$ & $32.3 \pm 3.4$ & $31.7 \pm 3.2$ & $.53 \pm .06$ \\
\hline Modifiers (\%) & $14.6 \pm 3.6$ & $15.5 \pm 3.3$ & $.60 \pm .13$ & $16.8 \pm 2.5$ & $17.4 \pm 3.3$ & $.55 \pm .09$ \\
\hline Independent words (\%) & $5.1 \pm 4.3$ & $5.0 \pm 2.7$ & $.67 \pm .24$ & $1.6 \pm 1.3$ & $2.1 \pm 1.2$ & $.77 \pm .29$ \\
\hline Relative words (\%) & $18.3 \pm 2.7$ & $11.7 \pm 2.0$ & $.37 \pm .11$ & $18.1 \pm 2.6$ & $10.3 \pm 1.8$ & $.31 \pm .07$ \\
\hline
\end{tabular}

Values are presented as mean \pm SD.

TTR=type-token ratio.

Table 5. Descriptive statistics for rate, TTR of word classes by semantic category

\begin{tabular}{|c|c|c|c|c|c|c|}
\hline \multirow{2}{*}{ Word class } & \multicolumn{3}{|c|}{ Elderly (N=35) } & \multicolumn{3}{|c|}{ Young (N=35) } \\
\hline & Token & Type & TTR & Token & Type & TTR \\
\hline Noun (\%) & $27.8 \pm 3.6$ & $35.4 \pm 3.7$ & $.71 \pm .09$ & $27.5 \pm 2.2$ & $33.6 \pm 3.4$ & $.65 \pm .07$ \\
\hline Pronoun (\%) & $4.5 \pm 1.7$ & $5.3 \pm 2.3$ & $.68 \pm .18$ & $2.6 \pm 1.2$ & $3.4 \pm 1.2$ & $.73 \pm .20$ \\
\hline Numeral (\%) & $2.8 \pm 2.2$ & $3.4 \pm 2.5$ & $.65 \pm .31$ & $1.1 \pm 1.0$ & $1.7 \pm 1.3$ & $.75 \pm .38$ \\
\hline Verb (\%) & $21.3 \pm 3.5$ & $17.7 \pm 3.0$ & $.46 \pm .09$ & $19.3 \pm 3.2$ & $19.2 \pm 3.3$ & $.54 \pm .09$ \\
\hline Adjective (\%) & $4.4 \pm 1.8$ & $5.1 \pm 1.6$ & $.68 \pm .18$ & $10.8 \pm 1.8$ & $11.4 \pm 1.8$ & $.58 \pm .13$ \\
\hline Copula (\%) & $1.1 \pm .9$ & $.8 \pm .5$ & $.40 \pm .37$ & $2.1 \pm 1.3$ & $1.1 \pm .5$ & $.38 \pm .29$ \\
\hline Determiner (\%) & $2.0 \pm 1.2$ & $2.6 \pm 1.3$ & $.72 \pm .29$ & $2.1 \pm 1.3$ & $2.3 \pm 1.4$ & $.56 \pm .28$ \\
\hline Adverb (\%) & $12.6 \pm 3.3$ & $12.9 \pm 2.7$ & $.59 \pm .14$ & $14.7 \pm 2.6$ & $15.0 \pm 2.9$ & $.56 \pm .11$ \\
\hline Exclamation (\%) & $5.2 \pm 4.3$ & $5.0 \pm 2.7$ & $.67 \pm .23$ & $1.6 \pm 1.3$ & $2.1 \pm 1.2$ & $.76 \pm .29$ \\
\hline Particle (\%) & $18.3 \pm 2.7$ & $11.7 \pm 2.0$ & $.37 \pm .11$ & $18.1 \pm 2.6$ & $10.3 \pm 1.8$ & $.31 \pm .07$ \\
\hline
\end{tabular}

Values are presented as mean $\pm S D$.

TTR= type-token ratio. 
Table 6. Predicative use and attributive use in inflectional word

\begin{tabular}{lcclcc}
\hline \multirow{2}{*}{ Inflectional words } & \multicolumn{2}{c}{ Elderly (N=35) } & & \multicolumn{2}{c}{ Young (N=35) } \\
\cline { 2 - 3 } \cline { 5 - 6 } & $\begin{array}{c}\text { Attributive } \\
\text { use }(\%)\end{array}$ & $\begin{array}{c}\text { Predicative } \\
\text { use (\%) }\end{array}$ & & $\begin{array}{c}\text { Attributive } \\
\text { use (\%) }\end{array}$ & $\begin{array}{c}\text { Predicative } \\
\text { use (\%) }\end{array}$ \\
\hline Verb & $12.1 \pm 6.3$ & $87.9 \pm 6.3$ & & $21.3 \pm 8.5$ & $78.7 \pm 8.5$ \\
Adjective & $19.9 \pm 16.8$ & $80.1 \pm 16.8$ & & $33.1 \pm 12.0$ & $67.0 \pm 12.0$ \\
Copula & $3.8 \pm 11.2$ & $73.3 \pm 42.0$ & & $17.1 \pm 24.5$ & $77.2 \pm 30.9$ \\
Total of Inflectional & $13.2 \pm 5.6$ & $86.8 \pm 5.6$ & & $25.0 \pm 6.4$ & $75.0 \pm 6.4$ \\
$\quad$ words & & & & & \\
\hline
\end{tabular}

Values are presented as mean $\pm S D$.

체언을 설명하고 묘사하는 내용을 서술하는 쓰임을 말한다.

기존의 자료에서 모든 대상자가 산출한 용언인 동사와 형용사, 지정사를 대상으로 분석을 진행하였다. 전체 용언을 관형적용법의 동사, 서술적용법의 동사, 관형적용법의 형용사, 서술적용법의 형용 사, 관형적용법의 지정사, 서술적용법의 지정사, 총 6 가지로 분류하 였다. 또한 위 6 가지 항목의 수치는 비율로 나타내기 위해 전체 동 사, 형용사, 지정사의 수로 각각 나누어 백분율을 산출하였다. 6 가 지 항목의 노년층과 청년층 간에 차이를 보기 위해 교육년수를 공 변량으로 한 공분산분석을 실시하였다.

Table 6을 살펴보면, 두 용법의 비율은 집단 간에 다르게 나타났 다. 첫째, 동사의 경우 노년층은 청년층보다 유의하게 더 적은 관형 적 용법 $(F=7.985, p=.006)$ 을, 그리고 더 많은 서술적 용법 $(F=7.977$, $p=.006)$ 을 사용하였다. 둘째, 형용사의 경우 노년층은 청년층보다 유의하게 더 적은 관형적 용법 $(F=4.020, p=.049)$ 을, 그리고 더 많 은 서술적 용법 $(F=4.020, p=.049)$ 을 사용하였다. 마지막으로 전체 용언으로 보았을 때, 노년층은 청년층보다 유의하게 더 적은 관형 적 용법의 용언 $(F=22.310, p<.001)$ 을, 그리고 더 많은 서술적 용법 의 용언 $(F=22.310, p<.001)$ 을 사용하였다.

\section{논의 및 결론}

본 연구에서는 일반 노년층과 청년층이 자발화 과제에서 산출한 품사의 양상을 비교하여 노년층의 발화 특성을 분석하였으며 그 논의와 결론은 다음과 같다.

첫째, 형식적 분류에 따른 품사를 살펴보면, 가변어에서는 노년 층이 청년층에 비해 더 적은 빈도수와 유형수를 사용하고, 불변어 에서는 더 많은 빈도수와 유형수를 사용하였다. 또한 노년층이 가 변어의 어휘다양도가 유의하게 낮았으므로 적은 종류의 가변어를 사용한 것을 확인할 수 있었다. 가변어는 기본형이 아닌 활용형으 로 나타나기 때문에 가변어의 사용 비율이 증가한다는 것은 문장 을 구성할 때 더 많은 문법형태소를 요구한다는 것을 의미한다(Kim
$\& \mathrm{Kim}, 2011)$. 노년층은 가변어의 사용이 감소하였으므로 적은 문 법형태소를 활용하여 문장을 산출하였다고 볼수 있다.

둘째, 기능적 분류에 따른 품사를 살펴보면, 집단 간에 유의한 차 이를 보인 것은 관계언을 제외한 모든 품사로 체언, 용언, 수식언, 독 립언이었다. 먼저 체언에서는 노년층이 청년층에 비해 빈도수를 더 많이 산출하였다. 하지만 체언의 유형수와 어휘다양도는 집단 간에 차이가 없었다. 노년층은 청년층보다 더 다양한 체언을 사용하지 않았지만 같은 단어를 반복하여 높은 비율로 사용하는 것이다. 그 다음, 용언을 살펴보면, 노년층이 청년층에 비해 빈도수와 유형수 모두 더 적게 산출하였다. 또한 노년층이 용언의 어휘다양도가 유 의하게 낮았으므로, 용언의 사용의 비율이 낮았을 뿐 아니라 빈약 한 어휘력을 보였다. 또한 용언의 추가 실험에서, 노년층은 청년층 에 비해 관형적용법을 더 적게 사용하였고, 서술적용법을 더 많이 사용하였다. 이러한 양상에 대한 원인으로 관형적 용법의 사용이 통사적으로 훨씬 복잡한 구조라는 것을 들 수 있다. 특히 실시간 대 화의 현장에서는 통사적으로 복잡한 내포문의 구조를 만드는 관형 적 용법의 사용이 비교적 힘들 수 있다(Bae, Choi, \& Kim, 2013). 정 상 노년층의 구문적 복잡성을 분석한 연구에서는 연령이 증가할수 록 구문적 복잡성이 감소하였고, 특히 70대 중반에 가장 빠른 속도 로 구문 능력이 저하되었다(Kemper, Thompson, \& Marquis, 2001). 본 연구에서 노년층의 관형적 용법의 저하도 위 선행연구를 뒷받침 하고 있다.

셋째, 의미적 분류에 따른 품사를 살펴보면, 집단 간 유의한 차이 를 보였던 것은 대명사, 동사, 형용사, 부사, 감탄사였다. 먼저 대명사 에서는 빈도수와 유형수 모두 노년층이 청년층에 비해 많이 산출 하였다. 대명사는 앞선 대화에서 이미 언급된 내용을 지적할 때 명 사 대신 사용하는 것이며, 구체적인 어휘를 사용하지 않고 가리키 기만 하는 품사로 정의된다(Nam \& Koh, 2011). 노년층에서 대명사 의 사용이 늘어났다는 것은 앞서 언급한 내용을 다시 말할 때 대용 어를 사용하거나, 구체적인 어휘를 사용할 부분에 상황적 지시어로 대신하는 비율이 높아졌다는 것을 알 수 있다(Kim \& Kim, 2009; Park \& Kim, 2013). 그 다음, 동사를 살펴보면, 노년층은 청년층에 비해 더 많은 빈도수를 사용하였다. 노년층의 동사산출 비율이 높 아진다는 선행연구(Critchley, 1984)의 결과와 일치하고 있다. 하지 만 동사의 어휘다양도는 노년층에서 더 낮게 나타나, 노년층이 높 은 비율로 동사를 사용하였지만 적은 종류의 어휘를 사용하여 같 은 단어를 반복하였다는 것을 알 수 있다. 다음으로, 형용사에서는 노년층이 청년층에 비해 빈도수와 유형수 모두 더 적게 산출하였 다. 형용사는 본 연구에서 집단 간에 가장 두드러진 차이가 나타난 품사였다. 동사와 구별되는 형용사의 특징은 기본적으로 상태성의 
자질을 가지고 있으며, 사건의 서술이 아니라 대상에 대한 주관적 인 판단이나상태, 가치, 성질에 대한 서술을 하는 것이다(Yoo, 1998). 품사 발달 연구에 의하면, 최초에 명사와 감탄사가 나타나고 그 뒤 에 동사, 그 다음에 형용사와 부사, 대명사가 나타난다(Lee \& Cho, 1999). 명사가 가장 먼저 나타나고 후에 형용사와 동사가 나타나되, 형용사의 습득이 더 늦게 나타나는 것을 알 수 있다(Lee \& Cho, 1999). 즉 추상적인 형용사의 습득이 구체적인 동사의 습득보다 상 대적으로 어려움을 의미하는 것이다(Lee \& Cho, 1999). 노년층의 언어기능에 대한 연구(Critchley, 1984)에서는 노년층의 형용사와 동사의 비율(adjective/verb: AVR)을 살펴보았다. 나이가 증가함에 따라 형용사에 비하여 동사의 사용이 증가하는 경향을 보였고, $\mathrm{AVR}$ 은 낮아졌다. 본 연구에서 노년층의 형용사 산출의 비율이 감 소한 것은 위 연구(Critchley, 1984)의 결과를 지지하고 있다. 이처 럼 형용사는 노년기에 산출 비율의 감소가 다른 품사에 비해 두드 러질 수 있다는 특징을 보여주고, 의사표현 시 다양한 의미를 표현 하고 주관적인 묘사, 상태를 서술하는 것 등에 어려움을 겪을 수 있 다는 것을 알 수 있다. 다음으로 부사를 살펴보면, 노년층이 청년층 에 비해 빈도수와 유형수 모두 적게 산출하였다. 부사는 다른 말 앞 에 놓여 그 말의 뜻을 분명히 제한해주는 기능을 한다(Nam \& Koh, 2011). 이러한 부사를 사용하면 문장 성분들의 의미를 긴밀하게 하 고, 의미를 강조하거나 한정하게 된다. 노년층은 청년층과 비교하여 이러한 표현을 덜 하는 것으로 보인다. 마지막으로 감탄사는 유형 수를 노년층이 더 많이 산출하였다. 감탄사의 어휘다양도는 집단 간 차이가 없었는데, 노년층이 많은 유형수를 산출했지만 빈도수도 많이 산출한 경향성 $(p=.093)$ 을 보였다. 이때 감탄사 중의 대부분 은 발화 중 불필요하게 반복되거나 뜻을 담고 있지 않는 입버릇 등 의 단어가 많았다.

본 연구의 의의는 첫째, 여러 가지 분류방법에 따른 품사 산출 양 상에 따른 품사 사용의 특성을 여러 측면에서 분석하여 노년층의 발화 특징을 도출하였다. 선행연구에서 노년층의 용언의 사용이 감 소하고, 동사의 사용이 증가한다는 것은 모순되는 양상으로 여겨 졌었다. 본 연구는 이러한 양상이 노년층의 용언 내 형용사의 사용 이 두드러지게 감소했기 때문이었음을 밝혀, 상반되는 사용 특징 에 대한 구체적인 설명을 할 수 있었다. 둘째, 품사의 빈도수와 유형 수, 어휘다양도를 살펴봄으로써 발화의 빈도인 양적인 측면에서뿐 아니라 발화의 다양성인 질적인 측면에서 분석할 수 있었다. 하지 만 발화수가 증가할수록 어휘다양도의 수치가 낮아지는 경향이 있 다는 문제점이 지적되면서, 많은 연구자들이 어휘다양도보다 빈도 수와 유형수를 어휘능력 척도로 사용할 것을 제안하였다(Watkins, Kelly, Harbers, \& Hollis, 1995). 본 연구에서도 집단 간 빈도수와 유
형수의 수치는 유의한 차이를 보이는 항목이 비교적 많았으나, 어 휘다양도에서는 차이가 거의 나타나지 않았다. 따라서 본 연구는 자발화에서 어휘의 사용특성을 분석할 때 어휘다양도보다 빈도수 와 유형수의 수치가 더 민감한 척도라는 의견을 지지한다.

본 연구의 제한점 및 후속연구를 위한 제언은 다음과 같다. 첫째, 청년층과 노년층의 비교를 하기보다 30 대, 50 대, 70 대 등 연령이 고 르게 분포된 집단을 대상으로 비교한다면 연령의 변화가 미치는 영 향을 설득력 있게 설명할 수 있을 것이다. 둘째, 본 연구의 대상자였 던 노년층은 서울지역 복지관의 실버대학, 교회의 경로대학의 수강 생들로 비교적 높은 학력과 교육 배경을 지닌 사람들이었다. 따라 서 일반 노년층을 대표할 수 있는 샘플이라고 보기 힘들었다. 셋째, 본 연구는 여성만을 대상으로 하였기 때문에 노년층을 대표하는 발화 특성을 설명하기는 어려움이 있다. 성비를 통제하여 여성과 남성 모두 대상으로 한 연구를 통해 노년층을 대표할 수 있는 분석 이 필요하며, 이를 통해 성별에 따른 차이도 볼 수 있을 것이다. 넷 째, 노년층의 용언 사용에서 문장구성의 복잡성을 논하기 위해 문 장발화 단위 별 용언의 사용 양상을 측정하여 문장구성 능력을 분 석하는 것이 필요하다. 노년기 담화기능의 향상을 위한 언어중재에 서 위와 같은 결과를 참고한다면, 일상 대화나 병원에서의 진료 상 황 등 개인적인 경험이나, 의견, 상태를 설명해야 할 때, 세밀하고 다 양하게 표현하도록 도움을 줄 것이다.

\section{REFERENCES}

Bae, J. Y., Choi, J. D., \& Kim, M. K. (2013). Grammar strategies for integration of spoken and written language 1. Seoul: Pagijong Press.

Cheon, O. (2011). Characteristics of the discourse of the elderly in conversation, picture description, and storytelling (Master's thesis), Yonsei University, Seoul, Korea.

Choi, H. B. (1991). Korean grammar. Seoul: Jungeumunhwasa.

Critchley, M. (1984). And all the daughters of musick shall be brought low: language function in the elderly. Archives of Neurology, 41, 1135-1139.

Kang, A. Y. (2008). A study of syntactic ability in 20's, 40's, and 70's using elicited compound sentence task (Master's thesis). Nazarene University, Cheonan, Korea.

Kang, Y. (2006). A normative study of the Korean-Mini Mental State Examination (K-MMSE) in the elderly. Korean Journal of Psychology, 25, 1-12.

Kemper, S., Thompson, M., \& Marquis, J. (2001). Longitudinal change in language production: effects of aging and dementia on grammatical complexity and propositional content. Psychology and Aging, 16, 600. 
Kim, J. W., \& Kim, H. (2009). Communicative ability in normal aging: a review. Korean Journal of Communication Disorders, 14, 495-513.

Kim, S. J., \& Choi, H. J. (2012). Characteristics of verbal definitions in normal elderly Korean. Korean Journal of Communication Disorders, 17, 107117.

Kim, S. J., \& Kim, M. A. (2011). A research on the interlanguage of Chinese speaking Korean language learners: focusing on MLU and characteristics found in vocabulary usage. Cross-Cultural Studies, 22, 303-327.

Koo, B. K. (2010). A few issues on parts of speech in Korean. Morphology, 12, 179-199.

Le Dorze, G., \& Bedard, C. (1998). Effects of age and education on the lexicosemantic content of connected speech in adults. Korean Journal of Communication Disorders, 31, 53-71.

Lee, B. W. (2010). Korean grammar for Speech-language therapists. Cheonan: Nazarene Language Hearing Center.

Lee, H., Park, C. I., Park, E. S., \& Kim, H. (2003). A study on the relationship between the children's development of predicates and syntactic ability. Korean Journal of Communication Disorders, 8, 20-40.

Lee, J. H., \& Cho, B. W. (1999). The language development of one, two, three, and four year-olds in play context: a focus on the development of parts of speech. Journal of Future Early Childhood Education, 6, 209-237.

Lee, J. T. (2003). A study on Korean pre-nouns. Korean Language Research, (13), 167-187.

Lee, S. J., Kim, H., Seo, S., \& Kim, M. (2009). Patterns of word class production between picture description and narrative tasks in aphasia. Korean
Journal of Communication Disorders, 14, 470-483.

Lee, Y. M., \& Kim, H. (2001). An utterance analysis of conversations and picture description tasks of Korean adults. Korean Journal of Communication Disorders, 6, 40-52.

Nam, K. S., \& Koh, Y. K. (2011). The standard Korean grammar. Seoul: Top Publisher.

Park, B. R. (2013). Topic statement characteristics that are demonstrated through elder's narrative (Master's thesis). Daegu University, Daegu, Korea.

Park, J. H., \& Kim, W. S. (2013). The speech quality which it follows in normal aging and pathological aging: focusing on part of speech use. Journal of Rehabilitation Research, 17, 299-317.

Seo, S. (1998). Research and application of words frequency in based on corpus analysis: focus on Yonsei corpus. Hangeul, 242, 225-270.

Seo, S., \& Ku, H. J. (2002). The study of spoken Korean. Seoul: Hankookmunhwasa.

Shin, C. B. (2011). A study on the functions of discourse markers by interjections in Korean language: focusing on the speaker's discourse strategies (Master's thesis). Korea National University of Education, Cheongju, Korea.

Sohn, E. N., \& Kang, S. K. (2006). A study on story retelling in the adults. Journal of Speech \& Hearing Disorders, 15, 71-85.

Watkins, R. V., Kelly, D. J., Harbers, H. M., \& Hollis, W. (1995). Measuring children's lexical diversity differentiating typical and impaired language learners. Journal of Speech, Language, and Hearing Research, 38, 1349-1355.

Yoo, H. K. (1998). The study on Korean adjectives. Seoul: Hankookmunhwasa. 
Appendix 1. 품사 분류 기본 기준*

\begin{tabular}{|c|c|}
\hline 품사 분류 기본 기준 & 예시 \\
\hline \multicolumn{2}{|l|}{ 1. 단어 차원의 형태분석을 원칙으로 한다. 즉, 형태소 차원의 분석은 하지 않는다. 따라서 접두사, 접미사 등의 단위는 분석하지 않는다. } \\
\hline 2. 복합 명사의 경우 국립국어원 표준국어대사전에서 검색하여 하나의 단어로 검색이 가능한 경우에 한 단어로 인정한다. & $\begin{array}{l}\text { 모래사막 명사1 } \\
\text { 한국무용 명사1 }\end{array}$ \\
\hline 3. 연속된 수사의 경우, 사전에 등재된 ‘한두, 두세, 서너, 너댓...등’ 은 하나의 단어로 취급하며, 그 외에는 각각 개별 단어로 분석한다. & $\begin{array}{l}\text { 이천구년 } \text { 수사 } 3 \text {, 명사1 } \\
\text { 한두 마리 수사 } 1 \text {, 명사1 }\end{array}$ \\
\hline 4. 월, 요일의 이름은 하나의 단어로 취급한다. & 십일월 명사1 \\
\hline 5. 불완전하게 발화된 단어라도 품사를 추정할 수 있는 경우, 분석에 포함한다. & 갔을=동사 1 \\
\hline \multicolumn{2}{|l|}{$\begin{array}{l}\text { 6. 본용언이 보조용언과 결합되어 한 단어인지 구분이 명확하지 않은 경우, 국립국어원의 표준국어대사전에서 한 단어로 검색이 } \\
\text { 가응할 때, 한 단어로 취합한다. }\end{array}$} \\
\hline $\begin{array}{l}\text { 7. '하다', ‘되다’ 등과 같이 명사나 부사 등의 뒤에 붙어서 동사, 형용사를 만드는 접사와 결합된 합성어의 경우, 하나의 단어로 } \\
\text { 분석한다. 하지만 선행하는 명사에 조사가 붙을 때, 따로 떼어내어 '하다'를 하나의 독립된 동사로 보고 분석한다. }\end{array}$ & $\begin{array}{l}\text { 공부하다 동사 } 1 \\
\text { 평안하다 형용사 } 1 \\
\text { 공부를 하다 명사 } 1 \text {, 조사1, 동사1 }\end{array}$ \\
\hline 8. 불필요하게 연속적으로 반복하여 산출한 단어나 구, 절은 뒤에 나온 부분을 ( )안에 표시하고 이는 한 번만 산출된 것으로 분석한다. & 그래서(그래서) 부사1 \\
\hline \multicolumn{2}{|l|}{ 9. 종결어미를 보조사(예: 요)로 따로 분리하지 않고 하나의 종결어미로 처리한다. } \\
\hline 10. 한국어의 품사로 분류할 수 없는 외국어는 분석에서 제외한다. 단, 표준국어대사전에 존재하는 외래어는 분석에 포함한다. & 로맨틱하다 형용사1 \\
\hline
\end{tabular}

*국립국어원 표준국어대사전에서 부분인용. 


\section{국문초록}

\section{품사 산출 양상에 따른 여성 노년층의 발화 특성}

김지영 $\cdot$ 서상규 ${ }^{2} \cdot$ 조성래 ${ }^{3} \cdot$ 김향희 ${ }^{13}$

'연세대학교 대학원 언어병리학협동과정, ${ }^{2}$ 연세대학교 국어국문학과, ${ }^{3}$ 연세대학교 의과대학 재활의학교실 및 재활의학연구소

배경 및 목적: 자발화에 나타난 품사를 살펴봄으로써 화자의 표현 언어를 문법적으로 분석할 수 있다. 노년층과 청년층의 품사산출 양 상을 비교하여, 노년층의 발화 특성을 분석하고자 하였다. 방법: 노년층 35 명, 청년층 35 명에게 자발화를 수집하였고, 산출한 품사는 형 식, 기능, 의미에 따라 나누었다. 이에 따른 품사의 빈도수와 유형수, 어휘다양도의 수치를 나타내었다. 결과: 형식적 분류에서 노년층은 청년층에 비해 빈도수와 유형수 모두 가변어를 적게, 불변어를 많이 사용하였고, 가변어의 어휘다양도는 노년층이 낮았다. 기능적 분류 에서 노년층은 체언에서는 빈도수를 많이 사용하였으나, 용언에서는 빈도수와 유형수 모두 적게 사용하였고, 용언의 어휘다양도는 노 년층이 낮았다. 수식언은 빈도수를 적게, 독립언은 빈도수를 많이 산출하였다. 의미적 분류의 품사는 노년층이 대명사에서 빈도수와 유 형수 모두 많이 산출하였고, 동사에서는 빈도수를 많이 사용하였지만, 동사의 어휘다양도는 낮게 나타났다. 형용사와 부사에서는 노년 층이 빈도수와 유형수 모두 적게 산출하였다. 추가분석으로, 용언의 양상을 관형적용법, 서술적용법으로 나누었다. 노년층은 청년층에

비해 서술적용법의 사용 비율이 더 높았다. 논의 및 결론: 노년층은 청년층과 비교하여 품사 산출양상이 달라지는 것을 밝혔다. 품사 의 세 가지 분류방법을 통해 여러 측면에서 특징을 분석하였고, 빈도수, 유형수, 어휘다양도를 측정하여 양적 측면뿐 아니라 질적 측면 에서 발화특성을 살펴보았다.

핵심어: 노년층, 품사, 빈도수, 유형수, 어휘다양도

본 논문은 제1저자의 석사학위논문(2014)을 요약한 것임.

\section{참고문헌}

강안영(2008). 성인 초기, 중기 및 노년기의 복문 사용 평가. 나사렛대학교대학원 석사학위논문.

강연욱(2006). K-MMSE의 노인 규준 연구. 한국심리학회지, 25, 1-12.

김선정, 김목아(2011). 중국인 한국어 학습자의 중간언어 연구. 비교문화연구, 22, 303-327.

김수정, 최현주(2012). 노년층의 명사 정의하기 특성. 언어청각장애연구, 17, 107-117.

김정완, 김향희(2009). 노년층 의사소통능력에 대한 문헌 연구. 언어청각장애연구, 14, 495-513.

남기심, 고영근(2011). 표준국어문법론. 서울: 탑출판사.

박보란(2013). 노인의 담화에 나타난주제진술특성. 대구대학교대학원 석사학위논문.

박정호, 김화수(2013). 정상노화와 병리적 노화에 따른 발화특성: 품사사용을 중심으로. 재활복지, 17, 299-317.

배진영, 최정도, 김민국(2013). 구어 문어 통합 문법 기술1. 서울: 박이정.

유현경(1998). 국어 형용사 연구. 서울: 한국문화사.

이봉원(2010). 언어치료사를 위한 한국어문법. 천안: 나사렛언어청각센터.

이영미, 김향희(2001). 대화와 그림설명과제를 통한 한국성인 발화의 비교 분석. 언어청각장애연구, 6, 40-52.

이정화, 조부월(1999). 유아의 언어발달에 관한 연구: 놀이 장면에서의 품사별 어휘사용 향상을 중심으로. 미래유아교육학회지, 6, 209-237.

이현정, 박창일, 박은숙, 김향희(2003). 아동의 구문발달에 따른 용언의 발달. 언어청각장애연구, 8, 20-40.

천옥현(2011). 노년층의 담화특성. 연세대학교 대학원 석사학위논문.

최현배(1991). 우리말본. 서울: 정음문화사. 